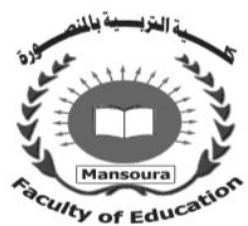

MANSOURA UNIVERSITY

FACULTY OF Education

A program based on Web 3.0 Tools to develop Secondary Private language Schools Students' EFL Productive Skills

\author{
By \\ Ebtesam Helmy Ahmed El Marakby
}

Supervisors

Prof. Aly Abdel-Samea Qoura Dr.Rehab Hamadtoh Gohar

Journal Of The Faculty Of Education- Mansoura University

No. 111 - July. 2020 


\title{
A program based on Web 3.0 Tools to develop Secondary Private language Schools Students' EFL Productive Skills
}

\begin{abstract}
This study aimed at investigating the effectiveness of using Web 3.0 tools for developing secondary stage students' EFL productive skills. Forty students from Future Language Schools, East Tanta Educational administration were selected as participants of the study. The study adopted the quasi-experimental design as the forty participants were divided into two groups. The experimental group was taught via using Web 3.0 tools (3D virtual classroom) while the control group was taught following the conventional instruction prescribed by the ministry of education in Egypt. The tools of the study included an EFL speaking skills test (pre \&post), an EFL writing skills test (pre \&post) and rubrics for scoring both speaking and writing tests. Analysis of the results revealed that the experimental group participants achieved a significantly higher level in their EFL productive skills than those of the control group. In the light of these results, it was concluded that Web 3.0 tools were effective to develop the second year secondary students' EFL productive skills.
\end{abstract}

Key words: Web 3.0 tools - 3D virtual classroom - EFL productive skills EFL secondary stage students.

\section{Introduction}

Speaking English is one of the productive skills and is regarded as a crucial part in teaching and learning English whether as a second or a foreign language. Speaking as a skill is necessary in English as a foreign language owing to the increasing number of learners who have the desire to speak English fluently and accurately mostly for communicative purposes. Moreover, Rivers (2010) argued that speaking is used twice as much as reading and writing in communication. Compared with writing, both of them are considered "productive skills" and opposed to the "receptive skills" of reading and listening.

Similarly, writing is one of the fundamental productive skills in learning English language. Brown (2001) considered writing in L2 from the perspective of teaching writing as one of the four skill areas. Abdel-Hack (2002) and El-Shafie (2006) stated that writing is the most difficult skill of all the language skills taught to EFL students. Students cannot develop their ideas when asked to write simple or compound sentences, and certain types 
of grammar mistakes dominate their writings. In addition, their sentences are almost Arabic structures literally translated. Their writing is unsatisfactory and poor and they are unable to express themselves in writing appropriately and correctly.

However, teaching English productive skills is a quite complex task for a teacher. Besides, language learning should be more fun and enjoyable for students to learn. Teachers need to have effective teaching strategies in order for students to grasp better in learning English. It is important for a teacher to facilitate students' interest towards learning the English Language (Amjah, 2014). With new technological tools continuing to emerge, multimedia plays very important role in English language teaching. The use of Multimedia presentation offers a potentially venue for improving students' understanding about language (Sharma, 2015).

Thus, a need for new strategies for incorporating all these factors has appeared. Therefore, the present study aims at investigating the effect of using Web 3.0 tools on developing speaking and writing skills for the second year secondary stage students.

\section{- Review of literature Speaking Skill}

Since communication is a two way process that includes receiving information and responding in the form of giving information, the received information covers listening and reading skills whereas speaking and writing skills are productive skills. A learner is considered to be a complete gainer of language when s/he speaks fluently and writes effectively (Sharma, 2015).

Speaking is one of the productive skills of English and it goes side by side with all language skills since learning to speak English is the shortest road to learn to read and write it (Aljadili, 2014). Hedge (2001) described speaking as a skill by which people are judged and first impressions are performed. Thus, speaking is important both as a first and a second/foreign language since it expresses people's personalities and thoughts. Andryani (2012) described speaking skill as the ability to speak the target language to communicate with others and it consists of accuracy, fluency, grammar, vocabulary, pronunciation and comprehensibility.

Kastoudi (2012) examined the potential of 3D Virtual quest games in second life (SL) to enhance vocabulary acquisition through interaction, negotiation of meaning and noticing. Qualitative analysis showed that there was a great amount of output and meaningful interaction, as well as negotiation of meaning, and small but substantial quantities of incidental 
learning of vocabulary occurred. Besides, the negotiation of meaning process itself facilitated the development of communicative competence.

Zourob (2014) conducted a study to investigate the effectiveness of using Webinar in improving speaking skills for The Rafah UNRWA seventh graders and their anxiety in speaking. The participants were equally divided into experimental and control group. The tools of the study were the achievement test, the observation card and the anxiety scale. Furthermore, the web based seminar was used for implementation. The results of the study revealed that webinar had positively affected the students' EFL skills and reduced their speaking anxiety.

Aljadili (2014) conducted a study to investigate the effectiveness of using virtual classes on developing the tenth graders' speaking skills and reducing their speaking anxiety. Two groups of 40 students from Khalid Bin Al Whalid Secondary School were randomly selected and divided into the experimental group of 20 students and control group of 20 students. For collecting data, the following tools were designed by the researcher: an oral test, a written speaking test and an anxiety scale. The experimental group studied in the virtual classes while the control group was taught using regular methods. Results of the study indicated the effectiveness of the virtual classes in improving pronunciation, fluency, organizing information, grammar and vocabulary for the experimental group in addition to reducing their speaking anxiety.

Similarly, a recent study by Lan (2014) aimed at determining the effectiveness of second life (SL) for improving the oral output of overseas Chinese students learning Mandarin Chinese. Results showed that learning Mandarin in a SL environment significantly increased the in-class oral output of those students, who also made significant improvements in oral performance and language learning attitudes.

Consequently, Speaking can be operationally defined as the ability to produce fluent, coherent and accurate speech to convey information, thoughts and feelings in a meaningful oral context using speaking skills (fluency, pronunciation, grammar, vocabulary and relevance to the topic).

\section{Writing Skill}

Writing is one of the most challenging skills that children are expected to master during their school years. As such, skilled writing is a complex communication activity that includes the acquisition, coordination, and integration of many processes and strategies (De La Paz \& Graham, 2002).

Writing is an essential communicative language skill. It is an activity that needs a mental effort to think out the sentences and the joining them to 
make them meaningful and communicative. However, it is not a skill to be learnt in isolation from the other language skills. (AL-Haq and AL-Sobh, 2010). The skills associated with writing must be mastered while in school, since successful participation in educational, work, and social settings beyond school require strong writing competence and overall literacy (Rutenberg, 2009).

Ahmed (2013) conducted a study to investigate the effect of using email on developing EFL writing skills among first year at Fakus Experimental Secondary School. Participants were divided into two groups: 30 students represented the experimental group and the 30 students represented the control group. The tools of the study were a pre-post e-mailwriting skills test, free-writing test and a rubric for scoring the tests. Both the experimental group and the control group were pre-post tested using the e-mail-writing skills test and the free-writing test. Results of the study showed that the experimental group outperformed the control group in the post-test of e-mail-writing skills test and the post- test of free-writing which proved that the program of e-mail was to be highly effective in improving first year secondary school students' EFL writing skills.

Suwantarathip (2014) conducted a study to examine the effects of collaborative writing activity using Google docs on students' writing abilities. The instruments employed in the study were writing tests and two questionnaires. Results of the study indicated that Students in the Google Docs group gained higher mean scores than those working in groups in a face-to-face classroom. In addition, students reported that they had positive attitudes toward collaborative writing activity and high collaboration in their groups using Google Docs, while nearly all of them perceived that this learning tool is easy to use.

An experimental study conducted by Sofia (2015) to investigate the effectiveness of using web 2.0 tools (Google Drive and Blog) in developing technical writing skills. Thirty four students from B.S. AbduRahman University at Vandalur, Chennai were the participants of the study. Tools of the study were two questionnaires, pre and post tests and three continuous tests. Data were collected using students' written assignments, questionnaire, continuous assignments and pre and posttests. Results revealed that Google Drive and Blog helped to improve students' technical writing and creating various opportunities for students to enhance the process of writing as well.

Abdallah and Mansour (2015) conducted a study to investigate the effectiveness of employing a virtual task-based situated language learning 
(TBSLL) environment mediated by Second Life (SL) in developing EFL the pragmatic writing skills of student teachers and their technological selfefficacy. Three measuring tools of the study were pre-post pragmatic writing skills test, self-efficacy scale and e-portfolio for formative assessment. Results showed that the virtual task-based situated language environment effectively developed pragmatic writing skills and that the technological self-efficacy for the participants of the experimental group was higher than those of the control group.

Hence forth,Writing is operationally defined in this study as the process of expressing thoughts and ideas in a readable form using some writing skills (content, cohesion, coherence, grammar, vocabulary and mechanics) on paper or the computer screen.

\section{Web 3.0}

Web 3.0 is the second phase of the Web evolution. In Web 1.0, producers just created contents for users to use and share it. In Web 2.0, users as well as producers participated in the content creation and sharing it. Web 3.0 has entirely changed the process by getting machines closer to the producer and users for more interactive, dynamic and effective creation of contents and managing it.

According to Singh et al., (2011), Web 3.0 can be defined as producing high-quality content and services by gifted individuals through using Web 2.0 technologies as enabling platform. This involves changing the web into a database that makes content available by using multiple nonbrowser application, the semantic Web, 3D Web and artificial intelligent technologies.

According to Lal (2011) Web 3.0 is characterized of being a media centric where users can locate the searched media in similar graphics and sound of other media formats. The pervasive nature of web 3.0 makes the users of web in wide range of area is reached not only in computers and cell phones but also through clothing, appliances, and automobiles.

Jauregi et al. (2012) studied the added value that synchronous collaboration projects through video-communication or SL might have in language learning. Results showed that tele collaboration experiences have an added value on cultural, linguistic, interpersonal and motivational issues. In particular, the synchronous learning environments used in conjunction with effective interaction tasks and the opportunities to engage in meaningful interaction with expert peers (native student teachers) contributed to empower intercultural learning experiences. 
Nomass (2013) presented a research paper that highlighted the role of using modern technology in teaching English. Different approaches and techniques would help English language students to improve their learning skills by using technology. Such techniques included online English language learning websites, computer assisted language learning programs, presentation software, electronic dictionaries, chatting and e-mail messaging programs, listening CD-players and learning video-clips. A questionnaire form had been used to assess how typical EFL classroom students benefit of technology in learning English. The results of this case study showed that the majority of the students preferred using technology, especially computers in developing their language skills.

Chen (2016) explored the EFL adult learners' perceptions and language practices in a task-based course in Second Life (SL). The study lasted for 10 sessions and handled the factors that affect SL learning experience and effects of task-based instruction on language learning in SL. Nine EFL adults from different countries were the participants of the study and gathered on a virtual island in SL (VIRTLANTIS). Participants were contacted through their English teacher and they were sent a timetable via Google Docs before the study to determine the most suitable time to attend the SL class synchronously. The data collected through two online questionnaires, learners' journals, group interview and observation. The results of the study indicated that 3D resources in SL provide EFL learners with visual and linguistic support and facilitate language teaching and learning. SL was proved to be a successful learning environment owing to its noticeable features and virtual reality.

Hsu (2017) conducted a study to develop and compare two Augmented Reality (AR) educational game systems for third graders to learn English vocabulary in situated surroundings. Tools of the study included pre-post test to assess the basic knowledge of students, questionnaires of learning styles, flow state, foreign language learning anxiety and cognitive load for measuring the students' performance. The results showed that the students using the self-directed or task-based AR educational game system had high learning effectiveness, although those using the self-directed system revealed higher flow experience. Yet, the students with a serial learning style had lower mental effort and foreign language learning anxiety regardless of using the self-directed or the taskbased AR educational game system.

As for this study, Web 3.0 tools can be operationally defined as electronic tools through which learners can be active participants in their 
learning process rather than being only recipients through being involved in virtual, collaborative environments and being able to access information whenever and wherever they are. Web 3.0 tools have some features such as distributed computing, extended smart mobile technology, collaborative intelligent filtering, 3D visualization and interaction. One of Web 3.0 tools adopted in this study was 3D virtual classes.

\section{- Statement of the problem}

Based on the literature review and related studies, the researcher's experience as a teacher for 20 years, it's clear that 2nd year secondary students at Future Language Schools in Tanta City were in need for improvement in their EFL productive skills through using new and active learning strategies to give them the chance to take part in their learning. Therefore, the present study investigated the effectiveness of using a program based on Web 3.0 tools in improving secondary students' EFL productive skills (speaking and writing).

\section{- Questions of the study}

The present study attempted to find answer to the following main question:

What is the effectiveness of using a program based on Web 3.0 tools in improving 2ndyear secondary students' EFL productive skills?

For research purposes, the following sub-questions were derived from this main question:

1. What are the features of Web 3.0?

2. How far would the use of a program based on Web 3.0 tools develop 2nd year secondary students' EFL speaking skills?

3. How far would the use of a program based on Web 3.0 tools develop 2nd year secondary students' EFL writing skills?

\section{- Purpose of the study}

The researcher sought to achieve the following purposes:

1. Identifying the effectiveness of using a program based on Web 3.0 tools in developing 2nd year secondary students' EFL speaking skills.

2. Identifying the effectiveness of using a program based on Web 3.0 tools in developing 2nd year secondary students' EFL writing skills.

\section{- Hypotheses of the study:}

In the light of the literature review and related studies and to achieve the purpose of the study as well, the following hypotheses were formulated:

1- Using Web 3.0 tools will improve EFL speaking skills for 2nd year secondary students. 
2-Using Web 3.0 tools will improve EFL writing skills for 2nd year secondary students.

For statistical purposes, hypotheses were formulated as follows:

1-There is a statistically significant difference at 0.05 level between the mean score of the control group and those of the experimental group on the post administration of the speaking test in favor of the experimental group.

2-There is a statistically significant difference at 0.05 level between the mean score of the experimental group pre-post administration of speaking test in favor of the post administration.

3-There is statistically significant difference at 0.05 level between the mean score of the control group and those of the experimental group on the post administration of the writing test in favor of the experimental group.

4-There is a statistically significant difference at 0.05 level between the mean score of the experimental group pre-post administration of the writing test in favor of the post administration.

\section{- Method \\ Participants}

The participants were two 2nd year secondary classes from Future Language Schools in Tanta city. One class of 20 students represented the experimental group and received a training program based on Web 3.0 tools. The other class of 20 students served as a control group and received only the regular teaching.

\section{Design}

This study is a quasi-experimental one. Two groups were assigned as the participants of the study; the experimental group and the control group. Both experimental and control groups were pre-post tested to determine their actual performance in EFL speaking and writing skills. The experimental group received instruction through the proposed program using Web 3.0 tools that include 3D virtual classroom in the computer lab whereas the control group received instruction through the regular methods of teaching in the classroom. The experiment lasted for six weeks during the second semester of the academic year 2018-2019.

\section{Instruments:}

For the purpose of this study, the following instruments were designed and used: 
1- An EFL speaking test for assessing 2nd year secondary students' EFL speaking skills in addition to a rubric for scoring students' speaking performance.

2- An EFL writing test for assessing 2nd year secondary students' EFL writing skills in addition to a rubric for scoring students' writing performance.

\section{- Results and discussions}

The results of the study are statistically analyzed in terms of its hypotheses and they are discussed in the light of the theoretical background and related studies. Results of the study were reported as follows:

Table (1): Comparing the performance of the control and experimental groups on the post-administration of the speaking skills

test

\begin{tabular}{|c|c|c|c|c|c|c|}
\hline$\frac{\infty}{\bar{n}}$ & Group & $\mathbf{N}$ & Mean Rank & Sum of Ranks & Mann-Whitney U & $\begin{array}{c}\text { Sig. } \\
\text { (2-tailed) }\end{array}$ \\
\hline \multirow{3}{*}{ 导 } & control & 20 & 13.55 & 271.00 & 61 & \multirow{18}{*}{ 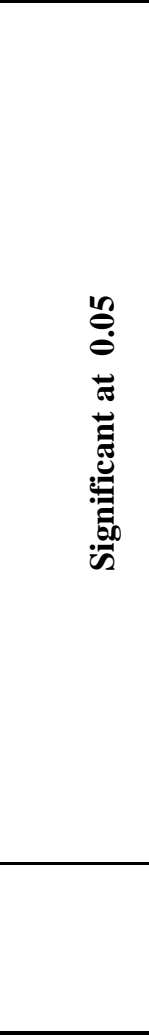 } \\
\hline & experimental & 20 & 27.45 & 549.00 & & \\
\hline & Total & 40 & & & & \\
\hline \multirow{3}{*}{ 苟 } & control & 20 & 12.65 & 253.00 & 43 & \\
\hline & experimental & 20 & 28.35 & 567.00 & & \\
\hline & Total & 40 & & & & \\
\hline \multirow{3}{*}{ 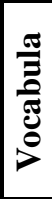 } & control & 20 & $M, \Lambda T$ & rV $7,0$. & 66.5 & \\
\hline & experimental & 20 & $r V, 1 \wedge$ & $0 \leqslant r, 0$. & & \\
\hline & Total & 40 & & & & \\
\hline \multirow{3}{*}{ 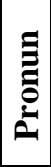 } & control & 20 & 12.52 & 250.50 & 40.5 & \\
\hline & experimental & 20 & 28.48 & 569.50 & & \\
\hline & Total & 40 & & & & \\
\hline \multirow{6}{*}{ 范 } & control & 20 & 11.80 & 236.00 & 26 & \\
\hline & experimental & 20 & 29.20 & 584.00 & & \\
\hline & Total & 40 & & & & \\
\hline & control & 20 & 11.45 & 229.00 & 19 & \\
\hline & experimental & 20 & 29.55 & 591.00 & & \\
\hline & Total & 40 & & & & \\
\hline
\end{tabular}


Results in Table (1) show that there is a significant difference between the mean rank of both the experimental and control groups in favor of the experimental one in the five skills and in the total score on the postadministration of the test. The variance between both the experimental and the control groups according to mean ranks and $U$ values lead to verifying the first hypothesis of the present study.

Table (2): Comparing the pre-post performance of the experimental group on the speaking skills test

\begin{tabular}{|c|c|c|c|c|c|c|c|}
\hline$\frac{n}{\bar{n}}$ & Ranks & $\mathrm{N}$ & Mean Rank & Sum of Ranks & $\mathrm{Z}$ & $\begin{array}{l}\text { Value of Eta-square } \\
\qquad(\eta 2)^{*}\end{array}$ & $\begin{array}{c}\text { Sig. } \\
\text { (2-tailed) }\end{array}$ \\
\hline \multirow{4}{*}{$\begin{array}{l}\text { 仓े } \\
\stackrel{0}{0} \\
\stackrel{\vec{I}}{\mid}\end{array}$} & Negative Ranks & 0 & .00 & .00 & \multirow{4}{*}{3.75} & \multirow{4}{*}{0.84} & \multirow{24}{*}{ 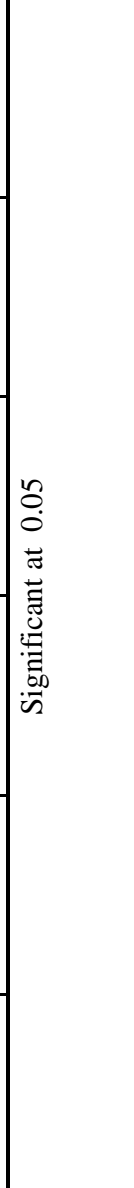 } \\
\hline & Positive Ranks & 18 & 9.5 & 171.00 & & & \\
\hline & Ties & 2 & & & & & \\
\hline & Total & 20 & & & & & \\
\hline \multirow{4}{*}{$\begin{array}{l}: \vec{\Xi} \\
\stackrel{\Xi}{\Xi} \\
\tilde{\Xi}\end{array}$} & Negative Ranks & 0 & .00 & .00 & \multirow{4}{*}{3.76} & \multirow{4}{*}{0.84} & \\
\hline & Positive Ranks & 18 & 9.5 & 171.00 & & & \\
\hline & Ties & 2 & & & & & \\
\hline & Total & 20 & & & & & \\
\hline \multirow{4}{*}{ 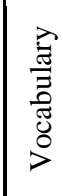 } & Negative Ranks & 0 & .00 & .00 & \multirow{4}{*}{3.733} & \multirow{4}{*}{0.83} & \\
\hline & Positive Ranks & 18 & 9.5 & 171.00 & & & \\
\hline & Ties & 2 & & & & & \\
\hline & Total & 20 & & & & & \\
\hline \multirow{4}{*}{ 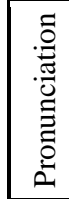 } & Negative Ranks & 0 & .00 & .00 & \multirow{4}{*}{3.83} & \multirow{4}{*}{0.86} & \\
\hline & Positive Ranks & 18 & 9.5 & 171.00 & & & \\
\hline & Ties & 2 & & & & & \\
\hline & Total & 20 & & & & & \\
\hline \multirow{4}{*}{ 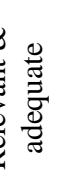 } & Negative Ranks & 0 & .00 & .00 & \multirow{4}{*}{3.94} & \multirow{4}{*}{0.88} & \\
\hline & Positive Ranks & 20 & 10.5 & 210 & & & \\
\hline & Ties & 0 & & & & & \\
\hline & Total & 20 & & & & & \\
\hline \multirow{4}{*}{ స్త్ర } & Negative Ranks & 0 & .00 & .00 & \multirow{4}{*}{3.92} & \multirow{4}{*}{0.88} & \\
\hline & Positive Ranks & 20 & 10.5 & 210 & & & \\
\hline & Ties & 0 & & & & & \\
\hline & Total & 20 & & & & & \\
\hline
\end{tabular}

Results in Table (2) show a statistically significant difference between the mean rank of students in the experimental group in the pre-post measurement in all skills of EFL speaking test and its total score. this 
finding agrees with some previous studies, for example, the results of Kastoudi (2012), Jauregi (2012), and Lan (2014) are in line with these of the present study in that using 3D virtual enviroments and Second Life (SL) have improved speaking skills as well as vocabulary acquisition and oral interaction. In addition, other previous studies supported using technology including web tools and internet tools and merging them with teaching to develop speaking skills, for example, Yunus et al. (2012), Owns (2012), Amin (2013), Baniabdelrahman (2013) and Pulsa (2015). The results of these studies confirmed the positive impact of different internet and web tools on EFL speaking skills. Furthermore, the results of such studies support the results of this present study that Web tools in general and Web 3.0 in particular have developed the EFL speaking skills of 2nd year secondary students.

Table (3): Comparing the performance of the control and experimental groups on the post-administration of the writing skills test

\begin{tabular}{|c|c|c|c|c|c|c|}
\hline 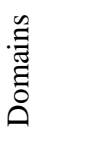 & Group & $\mathrm{N}$ & Mean Rank & Sum of Ranks & Mann-Whitney U & Sig. (2-tailed \\
\hline \multirow{3}{*}{ 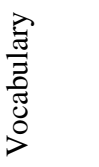 } & control & 20 & 13.00 & 260.00 & 50 & \multirow{18}{*}{ 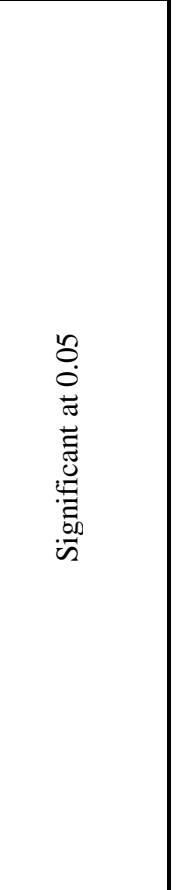 } \\
\hline & experimental & 20 & 28.00 & 560.00 & & \\
\hline & Total & 40 & & & & \\
\hline \multirow{3}{*}{ 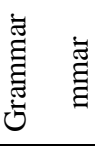 } & control & 20 & 13.98 & 279.50 & 69.5 & \\
\hline & experimental & 20 & 27.02 & 540.50 & & \\
\hline & Total & 40 & & & & \\
\hline \multirow{3}{*}{ 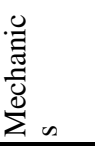 } & control & 20 & 13.32 & 266.50 & 56.5 & \\
\hline & experimental & 20 & 27.68 & 553.50 & & \\
\hline & Total & 40 & & & & \\
\hline \multirow{3}{*}{ 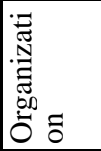 } & control & 20 & 12.42 & 248.50 & 38.5 & \\
\hline & experimental & 20 & 28.58 & 571.50 & & \\
\hline & Total & 40 & & & & \\
\hline \multirow{3}{*}{ 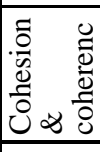 } & control & 20 & 10.88 & 217.50 & 7.5 & \\
\hline & experimenta & 20 & 30.12 & 602.50 & & \\
\hline & Total & 40 & & & & \\
\hline \multirow{3}{*}{ 吾 } & control & 20 & 10.68 & 213.50 & 3.5 & \\
\hline & experimental & 20 & 30.32 & 606.50 & & \\
\hline & Total & 40 & & & & \\
\hline
\end{tabular}

As shown in table (3) Mann-Whitney value is (3.5) and this indicates that the differences between the mean rank of the students in the control and 
experimental groups were statically significant at 0.05 levels in favor of the experimental group due to the administration of the proposed program based on Web 3.0 tools. Henceforth, the third hypothesis can be accepted.

Table (4): Comparing the pre-post performance of the experimental group on the writing skills test

\begin{tabular}{|c|c|c|c|c|c|c|c|c|}
\hline 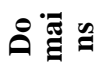 & Ranks & $\mathbf{N}$ & $\begin{array}{l}\text { Mean } \\
\text { Rank }\end{array}$ & $\begin{array}{l}\text { Sum of } \\
\text { Ranks }\end{array}$ & $\mathbf{Z}$ & $\begin{array}{l}\text { Value of Eta- } \\
\text { square }(\eta 2)^{*}\end{array}$ & $\begin{array}{l}\text { Level of } \\
\text { effect size }\end{array}$ & $\begin{array}{l}\text { Sig. (2- } \\
\text { tailed) }\end{array}$ \\
\hline$\gtrsim$ & $\begin{array}{c}\text { Negative } \\
\text { Ranks }\end{array}$ & 0 & .00 & .00 & \multirow{4}{*}{3.74} & \multirow{4}{*}{0.84} & \multirow{4}{*}{ high } & \multirow{24}{*}{ 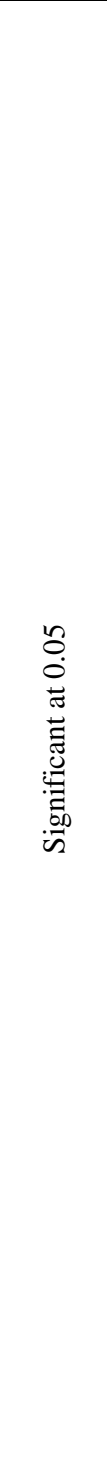 } \\
\hline $\begin{array}{l}\frac{\pi}{\Xi} \\
\frac{\pi}{\tilde{J}}\end{array}$ & $\begin{array}{l}\text { Positive } \\
\text { Ranks }\end{array}$ & 18 & 9.5 & 171.00 & & & & \\
\hline$>$ & Ties & 2 & & & & & & \\
\hline & Total & 20 & & & & & & \\
\hline & $\begin{array}{c}\text { Negative } \\
\text { Ranks }\end{array}$ & 0 & .00 & .00 & \multirow{4}{*}{3.735} & \multirow{4}{*}{0.84} & \multirow{4}{*}{ high } & \\
\hline 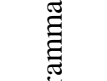 & $\begin{array}{l}\text { Positive } \\
\text { Ranks }\end{array}$ & 18 & 9.5 & 171.00 & & & & \\
\hline & Ties & 2 & & & & & & \\
\hline & Total & 20 & & & & & & \\
\hline \multirow{4}{*}{ 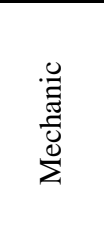 } & $\begin{array}{c}\text { Negative } \\
\text { Ranks }\end{array}$ & 0 & .00 & .00 & \multirow{4}{*}{3.5} & \multirow{4}{*}{0.78} & \multirow{4}{*}{ high } & \\
\hline & $\begin{array}{l}\text { Positive } \\
\text { Ranks }\end{array}$ & 16 & 8.5 & 136.00 & & & & \\
\hline & Ties & 4 & & & & & & \\
\hline & Total & 20 & & & & & & \\
\hline \multirow{4}{*}{ 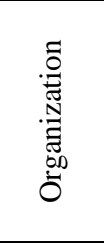 } & $\begin{array}{c}\text { Negative } \\
\text { Ranks }\end{array}$ & 0 & .00 & .00 & \multirow{4}{*}{3.83} & \multirow{4}{*}{0.86} & \multirow{4}{*}{ high } & \\
\hline & $\begin{array}{l}\text { Positive } \\
\text { Ranks }\end{array}$ & 19 & 10.00 & 120.00 & & & & \\
\hline & Ties & 1 & & & & & & \\
\hline & Total & 20 & & & & & & \\
\hline \multirow{4}{*}{ 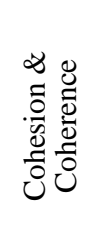 } & $\begin{array}{c}\text { Negative } \\
\text { Ranks }\end{array}$ & 0 & .00 & .00 & \multirow{4}{*}{3.828} & \multirow{4}{*}{0.86} & \multirow{4}{*}{ high } & \\
\hline & $\begin{array}{c}\text { Positive } \\
\text { Ranks }\end{array}$ & 19 & 10.00 & 190 & & & & \\
\hline & Ties & 1 & & & & & & \\
\hline & Total & 20 & & & & & & \\
\hline \multirow{4}{*}{$\stackrel{\pi}{0}$} & $\begin{array}{c}\text { Negative } \\
\text { Ranks }\end{array}$ & 0 & .00 & .00 & \multirow{4}{*}{3.921} & \multirow{4}{*}{0.88} & \multirow{4}{*}{ high } & \\
\hline & $\begin{array}{l}\text { Positive } \\
\text { Ranks }\end{array}$ & 20 & 10.5 & 210 & & & & \\
\hline & Ties & 0 & & & & & & \\
\hline & Total & 20 & & & & & & \\
\hline
\end{tabular}


These significant differences in the previous table are in favor of the post-test and these findings point to the effectiveness of the program based on Web 3.0 tools in improving students' EFL writing skills. Concerning the total value of the eta square for all the five domains, it is obvious that $88 \%$ of the total variance in overall writing skills can be ascribed to the implementation of the program based on Web 3.0 tools (3D virtual classroom).

These results came along with the results of some previous studies that examined the role Web 3.0 tools on improving students' EFL writing skills such as Munro (2010) and Abdallah \& Mansour (2015) whose studies aimed at developing writing skills using Second Life (SL) as one of Web 3.0 tools. Some studies clarified that students' writing skills were improved using earlier Web generations such as Web 2.0 tools. This is clear in studies as: Zhao (2010), Sofia (2015) and Al Khataybeh (2016). Most studies confirmed the role of using other technological tools on improving students' writing skills such Ahmed (2013), Li (2014), Gaith \& Awada (2014), Suwantarathip (2014), and Frison (2015).

\section{- Conclusions}

Results of the present study and discussion led to the conclusion that, it can be concluded that administering the proposed program based on Web 3.0 tools of the present study led to improving the experimental group students' speaking and writing skills than their colleagues of the control group. Furthermore, the results revealed that this program is more effective than regular methods for developing both speaking and writing as EFL productive skills.

\section{- Recommendations}

In the light of the present study, the following recommendations are stated:

1-Teachers are recommended to be aware of the importance of modern Web 3.0 tools in developing students' EFL productive skills.

2-Teachers' roles should be changed from being the only source for information to be a facilitator, guide, monitor and a consultant.

3-Teachers are recommended to think of using different Web 3.0 tools with other skills such as listening and reading.

4-Teachers are suggested to attend training courses that qualify them to use modern methods in teaching with technology integration.

5-Course designers are advised to include new methods in teaching English depending on using educational online tools.

\section{References}


Abdallah, M., \& Mansour, M. M. (2015). Virtual task- based situated language-learning with second life: Developing EFL pragmatic writing and technologicalself-efficacy. ArabWorld English Journal (AWEJ), Special Issue on CALL, (2), 150-182.

Abdel-Hack, I. (2002). The Effectiveness of a task-based learning approach on EFL students' writing production. Occasional papers in the development of English language education (Issued by: Center for Developing English Language Teaching "CDELT"), 34, 193-231.

Ahmed, M. A. E. A. S. (2013). The Effect of Using E-mail on Developing EFL Writing Skills for Secondary Stage Students at the Experimental Schools. Arab World English Journal, 4(3).

Alhaq, F \& Alsobh, M.(2010). The effect of a web- based writing instructional EFL program on enhancing the performance of Jordanian secondary students. The Jalt CALL Journal, 6(3), 184-218.

Aljadili, M. (2014). The Effectiveness of Using Virtual Classes on Developing the Tenth Graders' Speaking Skills and Their Speaking Anxiety. Unpublished Master thesis, Islamic University, Palestine.

AL-Khataybeh, M. M., \& AL-Awasa, A. S. (2016). The Effect of Using Web Quests on Improving Seventh Grade

Female Students' Writing Skills in Southern AL-Mazar Directorate of Education.

Amin, S. (2013). An Effective use of ICT for Education and Learning by Drawing on Worldwide Knowledge, Research, and Experience. Scholarly Journal of Education, 2 (4), 38, 45.

Amjah, D. Y. P. H. (2014). A study of teachers' strategies so develop students' interest towards learning English as a second language. Procedia-Social and Behavioral Sciences, 134, 188-192.

Andryani, L. (2012). Improving students speaking skill through socio drama. Journal of Instructional Psychology. 37. (2). Available at : www.proquest .com

Chen, J. C. (2016). The crossroads of English language learners, taskbased instruction, and 3D multi-user virtual learning in Second Life. Computers \& Education, 102, 152-171

De La Pas, S. \& Graham, S. (2002). Explicitly strategies, teaching skills, and knowledge: Writing instruction in classrooms. Journal of Educational 687-698. DOI: 10.1037//0022middle school Psychology, 94(4), 0663.94.4.687 
El-Shafie, S. (2006). The effectiveness of using computers in improving English composition writing for secondary stage students. Unpublished M.A. Thesis. Faculty of Education, Menoufia University.

Hedge, T. (2001). Teaching and Learning in the Language Classroom, 106, UK: Oxford University Press.

Hsu, T. C. (2017). Learning English with augmented reality: Do learning styles matter?. Computers \& Education, 106, 137-149.

Jauregi, K., de Graaff, R. \& Canto, S. (2012). Integrating Interaction through Videocommunication\& Virtual Worlds in FLT Programs: Burden or Added Value? The EUROCALL Review.Proceedings of the EUROCALL 2011 Conference.20, 83-86.

Lal, M. (2011). Web 3.0 in Education \& Research. BVICAM's International Journal of Information Technology, 3(2).

Lan, Y.J. (2014). Does Second Life Improve Mandarin Learning by Overseas Chinese Students? Language Learning \& Technology, $18,2,36-56$.

Luama, S. (2004). Assessing Speaking. Cambridge: Cambridge University Press.

Nomass, B. (2013). The Impact of Using Technology in Teaching English as a Second Language. English Language and Literature Studies; Vol. 3 , No. 1 .

Nunan, D. (2003). Practical English Language Teaching. New York :McGraw Hill Company.

Nunan, D. (2001). Second Language Teaching \& Learning. Heinle \& Heinle Publishers, 7625 Empire Dr., Florence, KY 41042-2978.

Owens, T. H. (2012). Smart Technologies in a Technology Classroom: Integration Investigation of Smart board and Smart Notebook into 7-12 Technology Education Classroom. Doctoral dissertation.

Pulsa, J. (2015). The use of online learning tools in practicing oral communication skills: a case study of upper secondary school students learner experiences on using Voxopop.

Rivers , N . (2010) . Language Acquisition and Production: Implications for Teaching Oral skills . Cambridge: Cambridge University Press.

Sharma, V. K. (2015). How do productive skills of Saudi students affect EFL learning and teaching. Asian Journal of Humanities and Social Sciences (AJHSS), 3(2).

Silva, J. M., Mahfujur Rahman, A. S. M., \& El Saddik, A. (2008). Web 3.0: a vision for bridging the gap between real and virtual. In Proceedings of the 1 st ACM international workshop on 
Communicability design and evaluation in cultural and ecological multimedia system (pp. 9-14). ACM.

Singh, K., Debi, \& Gulati, D. (2011). Technological March from Web 1.0 to Web 3.0: A Comparative Study. LIBRARY HERALD, 49(2), 146157.

Sofia H., (2015). Teaching technical writing skills Using web 2.0 technology-an Experimental study. Doctoral dissertation.B.S.AbdurRahman University.

Suwantarathip, O., \& Wichadee, S. (2014). The effects of collaborative writing activity using Google Docs on students' writing abilities. TOJET: The Turkish Online Journal of Educational Technology, 13(2).

Yunus, M. M., Kwan, L. S. L., \&Noriah, M. I. (2012). Benefits of using Web 2.0 technologies for English language learning: Gifted students'perception. In Proceedings of the 3rd International Conference on Arts and Culture (ICAC'12), Advances in Environment, Computational Chemistry and Bioscience (pp. 385-390).

Zourob, M. (2014). The Effectiveness of Using Webinar on Improving Speaking Skills for the Rafah UNRWA Seventh Graders and their Anxiety in Speaking. Unpublished M.ed thesis, The Islamic University. 